\title{
Receptors to fibrin fragments on neuroendocrine PC-12 cells
}

\author{
N. Chorna, Yu. Petrova, O. Kalashnyk, T. Platonova, S. Cederholm-Williams and \\ M. Skok
}

Palladin Institute of Biochemistry NAS of Ukraine

9 Leontovicha Street, Kyiv, 01601, Ukraine

1k56@yandex.ru

\begin{abstract}
By means of fluorescent flow cytometry and cell-based immunoenzyme assay, it is demonstrated that neuron-like cells of PC-12 cell line express $\alpha_{1} \beta_{3}$ integrin responsible for the binding of these cells to fibrinogen and D-, DD-, E-fibrin fragments. Each cell possesses approximately $1 \times 10^{6} D$-fragment binding sites; the affinity constant is $8.12 \times 10^{6} \mathrm{M}^{-1}$; the binding is blocked with the RGD-containing peptide. Internalization and subsequent restoration of the receptors on the membrane occurs in physiological conditions. Pre-incubation with fibrin fragments results in the increase of receptors density on the cell surface. D-, DD- and E-fragments adsorbed to the plastic favor PC-12 cell proliferation that explains positive effect of fibrin on nerve cells' renewal.
\end{abstract}

Key words: $P C-12$ cell line, D-, DD-and E-fibrin fragments, integrins.

Introduction. Regeneration of damaged peripheral nerves from traumatic injury is critical for functional recovery of tissues and organs. The first response to tissue damage is activation of blood coagulation/fibrinolysis systems leading to a fibrin clot formation and its subsequent degradation with proteolityc enzymes released by surrounding cells. Initially, the clot serves as a temporary matrix for the cells migrating to the site of injury [1]. Fibrin degradation products and fibrin itself are biologically active substances, stimulating the process of nerve regeneration [2]. Fibrin glue was suggested for nerves reconstruction $[3,4]$ and stabilization during surgery [5] as well as the repository improving rate and quality

(C) N. Chorna, Yu. Petrova, O. Kalashnyk, T. Platonova, S. CEDERHOLM-WILLIAMS AND M. SKOK, 2008 of regenerative process [6]. Despite the growing body of practical knowledge, the molecular mechanisms underlying the effects of fibrin degradation products on neuronal cells remain unknown.

Previously we demonstrated that rat pheochromocytoma PC-12 cells, a well-characterized cell line resembling sympathetic neurons when grown in the presence of nerve growth factors [7], stimulated the plasmin type of fibrin clot hydrolysis by secreting tissue plasminogen activator [8]. The resulting products of fibrin hydrolysis i.e. D-, DD- and Efragments influence the PC-12 cells viability due to the increase in their adhesive capacity [9].

The aim of this paper is identification of cell surface receptors mediating the effects of D-, DD- and E- fibrin(ogen) fragments in PC-12 cells. 
Materials and methods. PC-12 cells were a kind gift of Dr. L.Voitenko from Bogomoletz Institute of Physiology, Kyiv. Conditions of their culturing, as well as the procedures of fibrin purification and polymerization, have been described previously [8]. D-, DD- and E- fibrin fragments were obtained according to [10-11].

The adhesion capacity of PC-12 cells was studied on non-adhesive plastic covered with the fibrin film, fibrinogen $(10 \mu \mathrm{g} / \mathrm{ml})$, gelatine $(0,6 \mathrm{mg} / \mathrm{ml}), \mathrm{D}-$, DD- or E-fibrin fragments $(10 \mu \mathrm{g} / \mathrm{ml})$. Protein solutions $(40 \mathrm{ml}$ per well) have been dried in the wells of 96-well bacteriological plates (Greiner, Germany) for $12 \mathrm{~h}$ at $37^{\circ} \mathrm{C}$, then the plates were washed three times with phosphate-buffered saline $\mathrm{pH} 7.4$ (PBS). The cells were placed into the wells in the culture medium for 1.5 $\mathrm{h}$ and then were washed out by gentle pipetting. The number of cells which remained attached was calculated by the MTT assay [12].

In some experiments, the cells were pre-incubated with the soluble DD-fragment for $30 \mathrm{~min}$ at $37^{\circ} \mathrm{C}$ before attaching to the adsorbed fragment. To determine the role of RGD site in PC- 12 cell binding to fibrin fragments the cells were attaching to adsorbed proteins in the presence of Arg-Gly-Asp-Ser peptide (Sigma, USA).

Binding of soluble fibrin fragments to PC-12 cells was studied directly by the cell-based immunoenzyme assay. The cells $\left(5 \times 10^{5}\right.$ per sample) were incubated in Eppendorf tubes with fibrinogen or fibrin fragments either on ice or at $37^{\circ} \mathrm{C}$. After subsequent washing, the cells were treated for $1 \mathrm{~h}$ either with rabbit fibrinogen-specific antibodies or D/E-fragment-specific antibodies, obtained by us previously. Endogenous peroxidase activity of the cells was blocked with $1 \%$ $\mathrm{H}_{2} \mathrm{O}_{2}$ during 20 min, after that the cell-bound antibodies were revealed with peroxidase-conjugated goat anti-rabbit immuno globulins (Sigma, USA). Peroxidase of the bound conjugate was developed with the substrate solution containing $0.4 \mathrm{mg} / \mathrm{ml}$ o-phenylendiamine and $0.05 \% \mathrm{H}_{2} \mathrm{O}_{2}$ in $0.05 \mathrm{M}$ $\mathrm{KH}_{2} \mathrm{PO}_{4}, \mathrm{pH}$ 5.0. The reaction was stopped with $4 \mathrm{~N}$ $\mathrm{H}_{2} \mathrm{SO}_{4}$, the cells were pelleted by centrifugation, while the supernatants were transferred to the wells of the 96-well plate to be read by Microelisa Autoreader (Dynatech, Switzerland) at $490 \mathrm{~nm}$.
In some experiments the cells were pre-incubated with the fibrin E-fragment in 1\% BSA-containing PBS for $2 \mathrm{~h}$ at $4^{\circ} \mathrm{C}$. After two washings with PBS they were incubated with the D-fragment $(10 \mu \mathrm{g} / \mathrm{ml}$ in BSA/PBS $)$ for additional $30 \mathrm{~min}$. The bound D-fragment was detected as described above.

The D-fragment was conjugated with fluorescein isothiocyanate (FITC) according to the procedure described in [13] for the investigation of the binding kinetics. The cell samples $\left(0.86 \times 10^{7}\right.$ per $\left.\mathrm{ml}\right)$ were treated with $50 \mu \mathrm{l}$ D-FITC $(0-200 \mu \mathrm{g} / \mathrm{ml})$ on ice during $30 \mathrm{~min}$. In some experiments the cells were pre-incubated with the non-labeled D- or E-fragments $(0-100 \mu \mathrm{g} / \mathrm{ml})$ for $60 \mathrm{~min}$ on ice and then washed twice with PBS. The fluorescence intensity of the cell-bound D-FITC was measured with MPF-4 spectrofluorimeter (Hitachi, Japan) using the excitation wavelength of 494 $\mathrm{nm}$ and the emission maximum at $520 \mathrm{~nm}$. Kinetic analysis was performed using the following equation [14]:

$$
Y /(1-Y)=K[X]
$$

where $\mathrm{X}$ - concentration of free D-FITC, Y bound D-FITC calculated as the part of saturating concentration taken for $1, \mathrm{~K}$ - affinity constant for the D-FITC binding. Bound D-FITC concentration at each titration point was calculated according to the standard curve built with soluble D-FITC. Free D-FITC concentration was determined as the difference between D-FITC added and bound. Affinity constant was calculated as a slope of the linear curve built within $\mathrm{Y} / 1-\mathrm{Y}$ and $\mathrm{X}$ coordinates. The Hill coefficient was calculated as the slope of the curve built within the Hill coordinates $\log \mathrm{Y} / 1-\mathrm{Y}$ and $\mathrm{X}$. The number of D-fragment binding sites per cell (n) was calculated according to the equation:

$$
\mathrm{n}=N \cdot B / C,
$$

where N - Avogadro's number, B - maximal saturating concentration upon D-FITC binding, C number of cells per $\mathrm{ml}$ [14].

The presence of $\alpha_{v} \beta_{3}$ integrin on PC-12 cells was detected by fluorescence flow cytometry using biotinylated goat antibodies against the $\mathrm{N}$-terminal part of rat $\alpha_{\mathrm{v}}$ integrin chain (sc-6617, Santa Cruz Biotechnology). The cells were incubated with the 

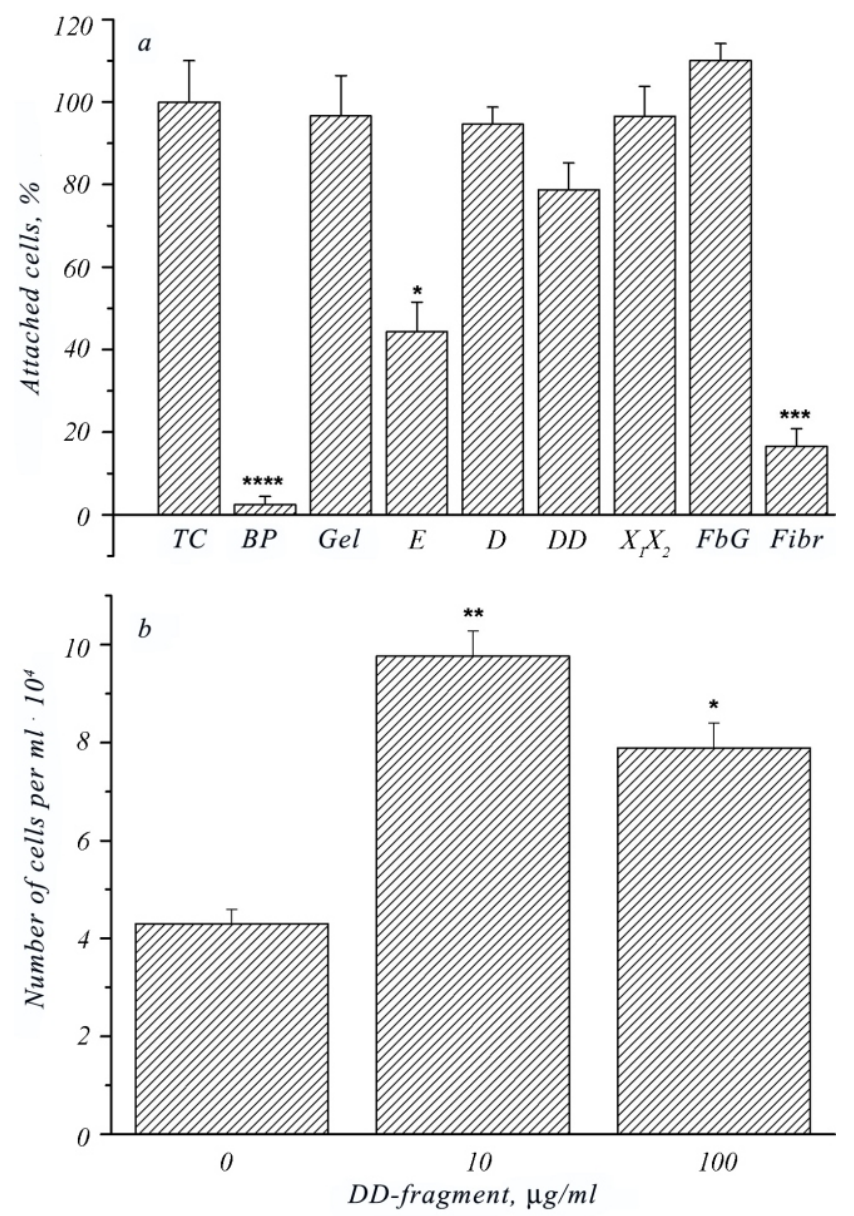

Fig. 1. Adhesion of PC-12 cells to tissue culture plastic (TC), bacteriological plastic (BP), bacteriological plastic coated with gelatin (Gel), E-, D- or DD-fragments, fibrinogen ( $\mathrm{FbG})$, mixture of fibrinogen $\mathrm{X}_{1}$ - and $\mathrm{X}_{2}$-fragments $\left(\mathrm{X}_{1} \mathrm{X}_{2}\right)$ or fibrin (Fibr); (a); adhesion to adsorbed DD-fragment upon pre-incubation with the soluble one (b). Significant difference is shown compared to TC (a) or to non-pre-incubated cells (b).

antibodies $\left(0.05-1 \mu \mathrm{g} \mathrm{IgG} \mathrm{per} 1 \times 10^{6}\right.$ cells) for $30 \mathrm{~min}$ at $4^{\circ} \mathrm{C}$ either with or without the 20 min pre-incubation with $1 \mu \mathrm{g} / \mathrm{ml}$ of fibrinogen. The bound antibodies were revealed with Streptavidin-phycoerythrine conjugate (BD PharMingen ${ }^{\mathrm{TM}}$ ), the fluorescence at $575 \mathrm{HM}$ was read by EPICS XL flow cytometer (Beckman Coulter).

All measurements have been made in triplicates. Statistical analysis has been performed according to the Student's t-test using OriginPro 7.5 software. The differences corresponding to $\mathrm{p}<0.05\left(^{*}\right), \mathrm{p}<0.005\left(^{* *}\right)$ and $\mathrm{p}<0.0005(* * *)$ were considered significant.

Results and discussion. Initially, we studied the PC-12 cells interaction with fibrin clots in 96-well plates as previously described [8]. According to the microscopic analysis, PC-12 cells remained round, unattached and avoided any contact with the clot during the experiment. Moreover, cells demonstrated relatively weak adhesion to the wells coated with fibrin although displayed strong adhesion to other coating agents, such as fibrinogen, fibrin fragments or gelatin, as well as to tissue culture plastic (fig.1, a). These data suggested that PC-12 cells express a wide spectrum of adhesion molecules including receptors to collagen (gelatin), vitronectin (which may adsorb to tissue culture plastic from the serum supplementing the culture medium) and fibrinogen, but not to fibrin. It is also possible that fibrinogen regions responsible for the receptor binding became less accessible after the fibrin clot formation, since high molecular weight fibrin degradation products displayed the receptor binding sites.

Pretreatment of PC-12 cells with soluble DD-fragment for $30 \mathrm{~min}$ increased their adhesion to the wells coated with DD-fragment as revealed by cell-based immunoenzyme assay (fig. 1,b). Similar effect was observed after the cells' pretreatment with soluble E-fragment, as demonstrated by the binding with both adsorbed D- fragment in immunoenzyme assay and soluble D-FITC in fluorescent spectroscopy (data not shown). These data indicated that binding of either D- or E-fragment triggers the corresponding receptor up-regulation and suggested that D- and Efragments are ligands of the same type of receptor.

As demonstrated by cell-based immunoenzyme assay, binding of D-/E-fragments to PC-12 cells evinced a saturation tendency at $4^{\circ} \mathrm{C}$. In contrast, at $37^{\circ} \mathrm{C}$, the increase in the fragments binding observed during the first $150 \mathrm{~min}$ was followed by the sharp decrease and slow recovery (fig.2). These results suggested that the receptors specific to fibrin fragments are internalized upon the ligand binding and then recycle to the membrane under physiological conditions.

Application of secondary antibody prevented the kinetic analysis of the receptors binding. Therefore, further studies were performed with the FITC-labeled D-fragment using fluorescent spectroscopy. We found that each PC-12 cell carried approximately $1 \times 10^{6}$ receptor-binding sites and the affinity constant of D-fragment binding to the cell surface was $8.12 \times 10^{6} \mathrm{M}^{-1}$. 


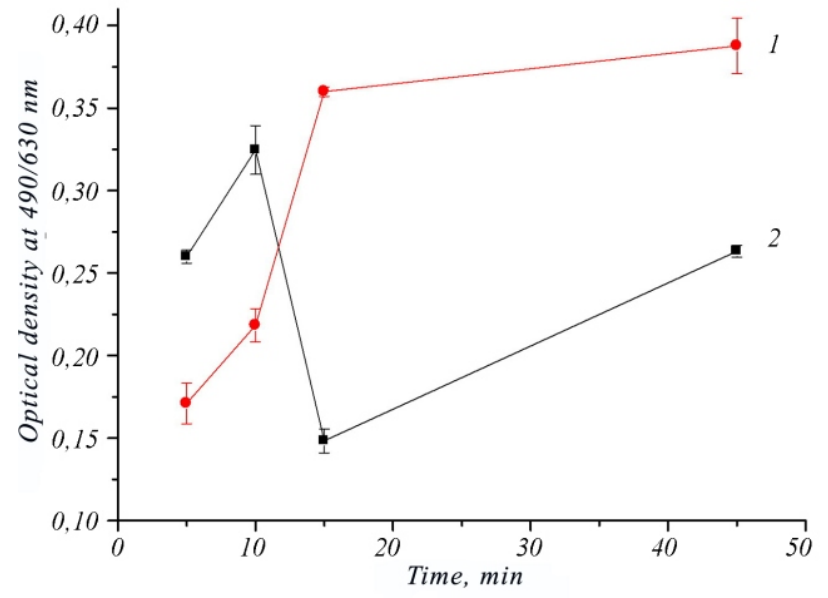

Fig. 2. D-fragment binding to $\mathrm{PC}-12$ cells under different temperature conditions: $1-4{ }^{\circ} \mathrm{C} ; 2-37^{\circ} \mathrm{C}$.
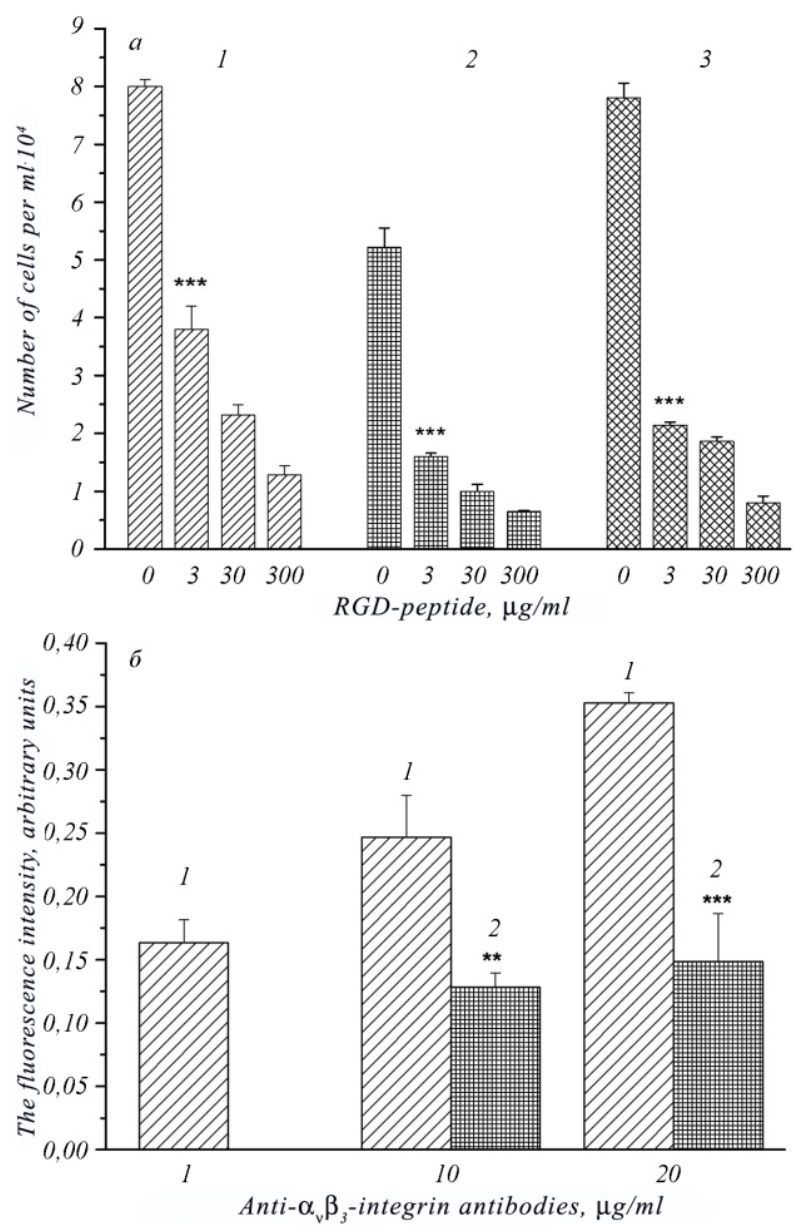

Fig. 3. Adhesion of PC-12 cells to adsorbed fibrinogen, D- and E-fragments in the presence of soluble RGD-peptide: 1 D-fragment; 2 - E-fragment; 3 - fibrinogen (a) and binding of anti$\alpha_{v}$-integrin antibodies with PC-12 cells in the absence (1) or presence (2) of fibrinogen in flow cytometry. Significant difference is shown compared to the cells incubated without RGD-peptide (a) or without fibrinogen (b).
The calculated Hill coefficient equaled to $0.698(<1)$ indicating the ratio of receptor-ligand binding to be $1: 1$.

Cell interactions with both extracellular matrix and blood coagulation proteins are being mediated by adhesion receptors called integrins. Many integrins recognize their ligands through the RGD binding site (the Arg-Gly-Asp sequence [15]). In our experiments, binding of PC-12 cells to fibrinogen and $\mathrm{D}$-/E-fragments decreased in the presence of RGD-containing peptide (fig.3, a). High receptor density on the cell surface (1x106 per cell) corresponded to known characteristics of integrins [16-17] including the level of their affinity and up-regulation after ligand binding.

RGD-dependent adhesion molecules able to bind fibrinogen are integrins $\alpha_{v} \beta_{3}, \alpha_{5} \beta_{1}$ and $\alpha_{\mathrm{IIb}} \beta_{3}[18,19]$. Integrin $\alpha_{\text {II }} \beta_{3}$ is expressed on cells affiliated to the megakaryocytic lineage and on haemopoietic progenitor cells [20]. Integrin $\alpha_{5} \beta_{1}$ preferably binds collagen and fibronectin. Therefore, we considered integrin $\alpha_{\downarrow} \beta_{3}$ as a probable target for the binding of fibrinogen and its fragments on PC-12 cells. The presence of this integrin was clearly demonstrated by flow cytometry technique. Antibodies against $\alpha_{v}$ chain bound PC-12 cells dose-dependently and the binding was diminished upon pre-incubation with fibrinogen (fig.3, b). This result is in agreement with literature data regarding PC-12 and other neuronal cells [21,22].

Integrin $\alpha_{\sqrt{v}} \beta_{3}$ can specifically bind fibrinogen through RGD-containing sequences A $\alpha 72-574$ and A $\alpha$ 95-97, previously indentified in the $\alpha$ chain of the C-terminal domain, as well as through RGD-dependent sites $190-202$ and $346-358$ in the $\gamma$-chain of the Ddomain [18]. PC-12 cells interacted with bovine fibrinogen and $X_{1}$ - and $X_{2}$ - fragments of human fibrinogen lacking 572-574 sequence (fig.1, $a$ ). The site $\mathrm{A} \alpha \mathrm{95-97}$ is lost after the cleavage of fibrin(ogen) by plasmin [23]. According to our data, PC-12 cells interacted with fibrinogen, D-, DD- and E-fragments in a similar way. Moreover, interaction of cells with the one fragment potentiated binding the others. Therefore, $\alpha_{v} \beta_{3}$ integrin binding site(s) presumably are present in every studied fragment.

It is recognized that the D (DD)-fragment contains RGD-binding sites (190-202 and 346-358) of the $\gamma$-chain [18], but no RGD-containing sequences in the 


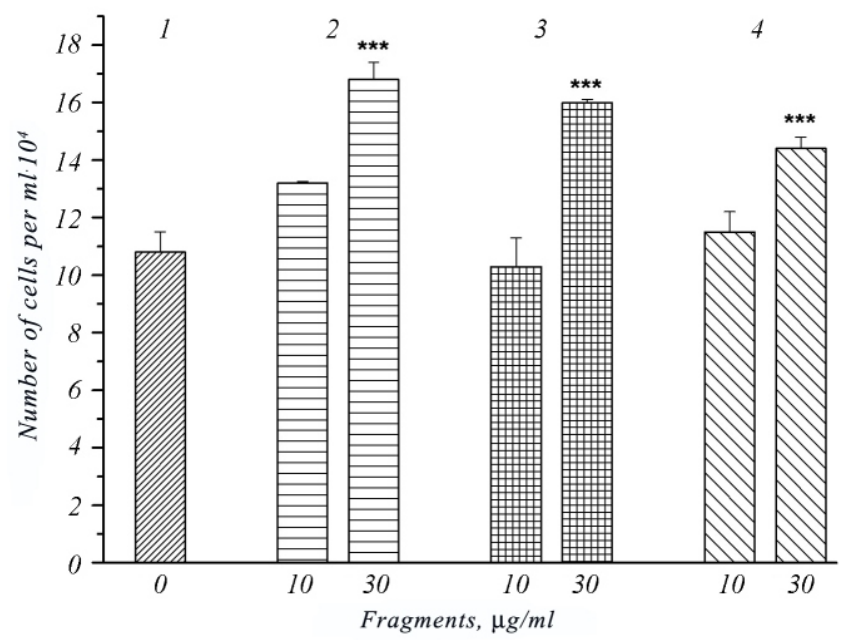

Fig. 4. PC-12 cells proliferation in the presence of D- (2); DD- (3) or E- (4) fibrin fragments adsorbed to tissue culture plastic; 1 - control; significant difference is shown compared to control cells (1) incubated without fibrin fragments.

E-fragment were reported. Our data suggest the presence of an additional RGD-binding site in the E-fragment. This site seems to be of lower affinity than the known sites on D(DD)-fragments, since PC-12 cells are attached to the E-fragment weaker than to the D-fragment (fig. 1, a). Our results are in agreement with those of Kodama et al [24] who showed that RGD-dependent migration of vascular smooth muscle cells into fibrin gels was blocked by both fibrin(ogen) D/E-fragments and corresponding antibodies.

Unlike soluble DD-, D- and E-fragments [9], those adsorbed to the plastic surface promoted proliferation of PC-12 cells (fig.4). It is quite possible that, under physiological conditions, the biological effects are exerted by the fibrin degradation products immobilized on surrounding tissues rather than by the soluble ones.

Overall, the data obtained suggest that the main fibrin(ogen) degradation products, i.e. DD-, D- and Efragments, stimulate adhesive and proliferative potential of neuronal cells through binding to integrin $\alpha, \beta_{3}$ receptors. This finding contributes to the understanding of positive effects of both fibrin clots (under natural condition) and fibrin glues (under surgery) on nerve regeneration.
Н. Ю. Чорна, Ю. І. Петрова, О. М. Калашник, Т. М. Платонова, С. Седерхольм-Вільямс, М. В. Скок

Рецептори до фрагментів фібрину на нейроендокринних клітинах РC-12

Резюме

Методами ичитофлуориметрії та клітинного імуноферментного аналізу показано, щчо нейроноподібні клітини лінії РС-12 експресують інтегрин $\alpha_{1} \beta_{3}$, відповідальний за зв'язування клітин з фібриногеном і $D$-, DD- та E-фрагментами фібрину. Кожна клітина містить приблизно $1 \cdot 10^{6}$ сайтів зв'язування D-фрагмента з константою афінності 8, $12 \cdot 10^{6} \mathrm{M}^{-1}$, зв'язування блокується $R G D$-вмісним пептидом. За фізіологічних температурних умов відбувається інтерналізація рецепторів 3 подальшим відновленням на мембрані. Передінкубаџія з фрагментами фібрину призводить до зростання кількості рецепторів на поверхні клітин. Адсорбовані на поверхні пластику D-, $D D$ - $i$ E-фрагменти фібрину сприяють проліферації клітин PC-12, щчо пояснює позитивний вплив цієї сполуки на відновлення нервових клітин.

Ключові слова: клітини лінї PC-12, D-, DD- i E-фрагменти фібрину, інтегрини.

Н. Ю. Черная, Ю. И. Петрова, Е. Н. Калашник,

Т. Н. Платонова, С. Седерхольм-Вильямс , М. В. Скок.

Рецепторы к фрагментам фибрина на нейроэндокринных клетках линии РС-12

Резюме

Методами циитофлуориметрии и клеточного иммуноферментного анализа показано, что нейроноподобные клетки линии РC-12 экспрессируют $\alpha_{\nu} \beta_{3}$-интегрин, ответственный за связывание клеток с фибриногеном и D-, DD-, E-фрагментами фибрина. Каждая клетка содержит приблизительно $1 \cdot 10^{6}$ сайтов связывания D-фрагмента з константой аффинности $8,12 \cdot 10^{6} M^{-1}$, связывание блокируется $R G D$-содержащчим пептидом. При физиологической температуре происходит интернализация рещепторов з последующим восстановлением на мембране. Преинкубация с фрагментами фибрина приводит к увеличению количества рецепторов на поверхности клеток. Адсорбированные на поверхности пластика $D$-, $D D$ - и E-фррагменты фибрина способствуют пролиферации клеток РC-12, что объясняет позитивное влияние фибрина на восстановление нервных клеток.

Ключевые слова: клетки линии PC-12, D-, DD- и E-фрагменты фибрин(ноге) а, интегрины.

\section{REFERENCES}

1. Akassoglou K., Kombrinck K. W., Degen J. L., Strickland S. Tissue plasminogen activator-mediated fibrinolysis protects against axonal degeneration and demyelination after sciatic nerve injury // J. Cell Biol.-2000.-149, N 5.-P. 1157-1166. 
2. Zeng L., Huck S., Redl H., Schlag G. Fibrin sealant matrix supports outgrowth of peripheral sensory axons // Scand. J. Plast. Reconstr. Surg. Hand Surg.-1995.-29, N 3.-P. 199204.

3. Matras H., Braun F., Lassmann H. Plasma clot welding of nerves (experimental report) // J. Max. Fac. Surg.-1973.-1.P. 236-247.

4. Dagum A. B. Peripheral nerve regeneration, repair and grafting // J. Hand Ther.-1998.-11, N 2.- P. 111-117.

5. Menovsky T., Bartels R. H. Stabilization and accurate trimming of nerve ends: practical use of fibrin glue: technical note // Neurosurgery.-1999.-44, N 1.-P. 224-229.

6. Yin Q., Kemp G. J., Yu L. G. Neurotrophin-4 delivered by fibrin glue promotes peripheral nerve regeneration // Muscle Nerve.-2001.-24, N 3.-P. 345-351.

7. Greene L. A., Tischler A. S. Establishment of a noradrenergic clonal line of rat adrenal pheochromocytoma cells which respond to nerve growth factor // Proc. Nat. Acad. Sci. USA.1976.-73.-P. 2424-2428.

8. Petrova Y.I., Savchuk O.M., Kalashnik O.M., Platonova T.M., Skok M.V., Cederholm-Williams S. PC-12 cells hydrolyze the fibrin clot by producing both plasminogen and its tissue activator // Ukr. Biochem. J.- 2004.- 76, № 2.- C. 64-68. [Ukrainian]

9. Kalashnik O.M., Petrova Y.I., Platonova T.M., Skok M.V., Cederholm-Williams $S$. The role of fibrin degradation products in the regulation of vital functions of PC-12 cells // Ukr. Biochem. J.- 2005.- 77, № 5.- C. 37-44. [Ukrainian]

10. Platonova T.M., Lukinova N.I., Medved L.V. Isolation and analysis of active forms of bovine fibrin D-dimer // Reports of Ukrainian Academy of Sciences - 1993.- 6.- C. 5-8. [Russian]

11.Belitzer V.O., Varetzka T.V., Tzinkalovska C.M., Pozdnyakova T.M., Tolstyh V.M. Isolation and study of fibrinogen high molecular weight trypsin fragment that inhibits polymerization of fibrin // Ukr. Biochem. J. - 1972.44, № 4.- C. 411-417. [Russian]

12. Carmichael J., DeGraff W. G., Gazdar A. F. Evaluation of a tetrazolium-based semiautomated colorimetric assay: assessment of radiosensitivity // Cancer Res.-1987.-47, N 4.-P. 943-946.

13. Claus J. Lymphocytes. Methods. - M.: MIR.- 1990. - 395 p. [Russian]

14. Cornish-Bowden A. Principles of Enzyme Kinetics. - M.: MIR. - 1979. - 280 p. [Russian]
15. Rovenskiy Y.A. Cellular and molecular mechanisms of tumor invasion // Biochimia. - 1998.- 63, №9. - C. 1204 - 1221. [Russian]

16. Bretscher M. S. Circulating integrins: $\alpha_{5} \beta_{1}, \alpha_{6} \beta_{4}$ and Mac-1, but not $\alpha_{3} \beta_{1}, \alpha_{4} \beta_{1}$ or LFA-1 // EMBO J.-1992.-11.- P.405410.

17. Critchley D. R. Focal adhesions - the cytoskeletal connection // Curr. Opin. Cell Biol.-2000.-12, N 1.-P. 133-139.

18. Yokoyama K., Erickson H. P., Ikeda Y., Takada Y. Identification of amino acid sequenses in fibrinogen gamma-chain and tenascin CC-terminal domains critical for binding to integrin alphavbeta 3 // J. Biol. Chem.-2000.-275, N 22.-P. 16891-16898.

19. Podolnikova N. P., Yakubenko V. P., Volkov G. L., Plow E. F., UgarovaT. $P$. Identification of a novel binding site for platelet integrins alpha IIb beta 3 (GPIIbIIIa) and alpha 5 beta 1 in the gamma C-domain of fibrinogen // J. Biol. Chem.-2003.-278, N 34.-P. 32251-32258.

20. Corbel C., Vaigot C., Salaun J. (alpha)IIb Integrin, a novel marker for hemopoietic progenitor cells // Int. J. Develop. Biol.-2005.-49, N 2-3.-P. 279-284.

21.Yip P. M., Zhao X., Montgomery A. M., Siu C. H. The Arg-Gly-Asp motif in the cell adhesion molecule L1 promotes neurite outgrowth via interaction with the alphavbeta3 integrin // Mol. Biol. Cell.-1998.-9, N 2.P. 277-290.

22.Pittier R., Sauthier F., Hubbell J. A., Hall H. Neurite extension and in vitro myelinization within three-dimensional modified fibrin matrices // J. Neurobiol.2005.-63, N 1.-P. 1-14.

23. Lougovskoi E.V. Molecular mechanisms of fibrin formation and fibrinolysis. - K.:Naukova dumka.- 2003.- 223 p. [Russian]

24. Kodama M., Naito M., Nomara H., Iguchi A., Thompson W. D., Stirk C. M., Smith E. B. Role of D and E domains in the migration of vascular smooth muscle cells into fibrin gels // Life Sci.-2002.-71, N 10.-P. 1139-1148.

UDC 577:27

Received 26.11.07 